\title{
Slovene-Medium and Bilingual Schools in Italy: Towards a New Paradigm?
}

\author{
Sara Brezigar \\ Institute for Ethnic Studies, Slovenia \\ sara.brezigar@guest.arnes.si
}

Over the past years, Slovene-medium kindergartens and primary schools in the region Friuli Venezia Giulia (FVG) have been trying to curb the trend of deteriorating linguistic skills among pupils by improving teaching methods, adjusting teaching contents, and developing teaching skills. The result of such efforts is not promising and the linguistic skills in the Slovene language continue to deteriorate from one generation of minority youth to the next. The paper presents the results of a recent preliminary study on the challenges faced by the aforementioned educational institutions, based on in-depth interviews and focus groups with teachers. The study seems to suggest that the adopted approach, which focuses primarily on 'linguistic' or 'didactic' issues, might be far too constrained to bring about the desired results, and a wider, contextual approach should be adopted to improve linguistic skills.

Keywords: bilingual kindergarten, language skills, Slovene language, minority language acquisition

\section{Introduction}

Slovene-medium kindergartens and primary schools in the region Friuli Venezia Giulia (FVG) form the core of the Slovene minority in Italy and represent an essential mechanism of its reproduction. For several decades they have faced demanding challenges, mostly stemming from the fact that an increasing number of children do not speak the minority language (or do so poorly) when enrolling into kindergartens and schools. A need arose for kindergartens and schools to reinvent themselves from institutions that teach 'in (or through)' the minority language to institutions that teach 'the' minority language. In too many instances their failure to do so led to poor linguistic skills in the minority language, endangering the minority's ability to reproduce itself.

In recent years, educational institutions have tried to deal with these challenges by improving teaching approaches and skills and adapting teaching contents in order to increase the proficiency of minority language speakers (Strani 2011; Mezgec 2008). Such efforts were promoted by actors in the schooling system (primarily teachers) as part of their professional training 
and additional project engagements at school. A prominent role in these efforts was also played by the civil society with numerous initiatives and projects aimed at improving the linguistic situation among youth, including innovative ways of combining afterschool activities with linguistic training, ${ }^{1}$ with additional linguistic and awareness raising workshops for teachers and trainers; ${ }^{2}$ with projects aimed at preparing additional educational materials that could be used by teachers, parents and other educators, ${ }^{3}$ and finally, with events and (online) tools aimed at sharing teaching experiences ${ }^{4}$ (Grgič 2017), educational materials and other resources that could help raise the effectiveness of linguistic teaching (Strani 2011).

Conceding that these efforts were not carefully planned, coordinated or managed and therefore conceding that their effectiveness was probably much lower than expected or hoped for, the end result is still less than promising and Slovene linguistic skills continue to deteriorate (Košuta and Toličič 1989; Kaučič-Baša 1994, Jagodic and Čok 2013; Jagodic 2011; Brezigar 2007; 2009; 2015; 2017).

Therefore, a preliminary exploratory study has been carried out among teachers and educators to identify the main factors conducive to poor linguistic skills in the Slovene language, and to uncover the causes of the schools' limited ability to improve such skills.

To put the study in an appropriate context, the first part of the paper will be devoted to presenting some basic data on the Slovene minority in Italy, its schooling system and challenges faced by both. The second part of the paper will offer a short overview of theoretical approaches that could be useful to understand the intricacies of the acquisition of the Slovene language in Italy. Finally, a short outline of the methodology of the study and its most salient results will be provided, ending with a discussion on possible ways forward.

\section{Slovene-Medium Kindergartens and Primary Schools}

The Slovene minority in Italy is an autochthonous minority ${ }^{5}$ settled in the North Eastern part of Italy, where its traditional settlement area in the re-

\footnotetext{
${ }^{1}$ An example of this is the Jezikovni poligon (Slosport 2016) that combined sports training with linguistic training.

${ }^{2}$ See, for example, the activities of the research institute SLORI in Trieste, the Zavod RS Slovenije za šolstvo and the Center za slovenščino kot drugi in tuj jezik.

${ }^{3}$ See, for example, the projects Eduka (http://www.eduka-itaslo.eu) and Edukaz (http://www .eduka2.eu), also in Brezigar and Zver (2019).

${ }^{4}$ See https://www.smejse.it.

${ }^{5}$ It's a traditional national minority in the sense that it represents a part of the Slovenian nation 'left over' in a neighbouring state (Petrič 1977), as a result of historical changes of state borders
} 
gion Friuli Venezia Giulia covers a total of 39 municipalities (Bogatec 2004b) in the former provinces of Gorizia (Gorica), Trieste (Trst) and Udine (Videm or Viden). A system of Slovene-medium public schools (consisting of kindergartens, primary and secondary schools) was set up in the provinces of Trieste and Gorizia in the aftermath of WWII (Bogatec 2004a). A private bilingual school in the province of Udine was established in the 1970 s to allow members of the Slovene minority to learn (also standard) Slovene ${ }^{6}$ in a school setting. The school was subsequently incorporated into the public schools' system. ${ }^{7}$

Slovene-medium kindergartens and primary schools in Italy were conceived as educational institutions where the teaching language was Slovene and the students were Slovene speakers, mostly members of the Slovene minority in Italy. Later on, however, the situation changed dramatically (Bogatec and Bufon 1996; 1999; Bogatec 2004b; 2010; Pertot 2002; 2009; 2011; Fatur 1989). By the end of the 2oth century a considerable number of children who did not speak the minority language were enrolling in Slovene-medium schools and kindergartens. Therefore, a need arose for kindergartens and schools to reinvent themselves from institutions that teach 'in (or through)' the minority language to institutions that teach 'the' minority language (Brezigar 2013; 2017).

The schooling system failed to acknowledge the new challenges and did not provide for special arrangements (e.g. additional support or teachers) for children who were not able to speak the minority language upon enrolment, hindering the efforts to improve the situation. It was left to the teachers to do their best, without the necessary skills to teach Slovene as $L 2$ and with very limited teaching resources that were rarely adapted to the minority environment, mostly provided by institutions in Slovenia. Above all, there were no linguistic standards that pupils would be required to achieve at each level of schooling. Finally, teachers (and principals) faced systemic barriers that un-

in Central Europe. There are no official data on the number of members of the Slovene minority in Italy, but estimates from 2002 suggest that there are 95.000 members of the Slovene minority (Bogatec 2004b), whereas an older, unofficial estimate of the Italian authorities suggested that there were ca. 80.000 members (Ministero dell'Interno 1994, 273).

${ }^{6}$ Most members of the Slovene minority in Italy speak both standard Slovene - which is the state and official language in the Republic of Slovenia - and its various local dialects or variants (Sussi 1998 in Vidau 2013, Janežič 2004 in Vidau 2013). Only in the province of Udine there are some members who only speak a local Slovene dialect, but are not able to speak standard Slovene, since they have not been able to pursue any form of formal education in Slovene.

${ }^{7}$ See Bogatec (2010) for a comprehensive longitudinal quantitative data analysis on bilingual education and Slovene-medium education in Italy. 
dermined the efforts of even the most determined among them, stemming primarily from the centralization, rigidity, and the operating procedures of the Italian public schools' system (Brezigar 2015).

An extensive qualitative study (Brezigar 2015) suggested that Slovenemedium and bilingual education did not result in a satisfactory (linguistic) reproduction of the Slovene minority in Italy, with interviewees pointing out that the minority educational system had not dealt adequately with the transition from teaching in the Slovene language (to mostly Slovene pupils or pupils from mixed marriages) to teaching the Slovene language (to a growing population of Italian and in some instances immigrant pupils). Experts listed the following factors as those contributing to this state of affairs: a lack of adequate teaching skills (and some institutional support, where educators, teachers and professors could acquire such skills); a lack of linguistic proficiency standards that should be achieved by children at various stages of schooling; a lack of teaching aids and materials for teaching Slovene to pupils who are not familiar with the language (Brezigar 2015).

Despite the strong effort to fulfil this gap (before and after the aforementioned study was conducted) by primarily developing teaching and linguistic skills, providing a supporting environment for minority language use with extracurricular activities, developing and producing the relevant teaching materials, ${ }^{8}$ and changing language attitudes among teachers, educators, trainers, etc. (Jagodic and Čok 2013; Pertot 2004), the results achieved are far from satisfactory, especially if we consider that after Slovenia's accession to the EU, the Italian majority population showed ${ }^{9}$ an increasing interest in the Slovene language, the Slovene minority and Slovenia (Brezigar 2013; Jagodic and Čok 2013; Bogatec 2010). This reflected also in an increased number of both adults and children learning Slovene (Jagodic and Čok 2013; Brezigar 2013).

It needs to be stressed that an increase of interest in a minority language does not necessarily lead to an increase in its use, and this was precisely the case of the Slovene language in Italy (Brezigar 2013; Jagodic and Čok 2013; Jagodic 2011; Bogatec et al. 2008; Kaučič-Baša 1997; 2002). Interest among

\footnotetext{
${ }^{8}$ See, for example, Strani (2011).

${ }^{9}$ Data on enrolment in Slovene-medium schools showed that the interest in the Slovene language increased significantly in the 9os and 2000s: The number of children from completely Italian families, where both father and mother identify themselves as Italians, rose from $7 \%$ to $24 \%$ of all enrolled children (Bogatec 2010). However, the trend seems to be reversing, since a negative trend in enrolments into Slovene-medium kindergartens has been observed since the school year 2013-2014.
} 
the majority population led to a rise in their enrolment in Slovene-medium kindergartens and schools, as well as sports and cultural clubs, music schools, etc. (Bogatec 2004b; 2010). In particular, those environments that had been traditionally monolingual Slovene (and represented an opportunity for the exclusive use of the Slovene language), such as kindergartens, schools or cultural and sports associations, were shifting at a growing speed towards bilingualism and in some cases even towards Italian monolingualism (Bogatec 2010; Maver 2015).

Paradoxically, although nowadays more people are able to speak (some) Slovene, in practice, less actually do so (Jagodic and Čok 2013; Brezigar 2013).

There are no longitudinal studies (or other objective measures) that monitor the levels of linguistic skills in Slovene-medium and bilingual schools over time. ${ }^{10}$ However, previous research (Brezigar 2013; 2015; Bogatec 2010; Bogatec et al. 2008; Kaučič-Baša 1997; 2002; Jagodic 2011), based primarily on qualitative studies, on experts' assessments and other indirect indicators related to language use and language preference, leaves little doubt about a significant decline in linguistic skills. Moreover, teachers included in this study confirmed on multiple occasions that the language of communication in several kindergartens and school had shifted (or was increasingly shifting) to the majority one. In the most extreme cases, the same happened with the language of instruction. Interviewee $1,{ }^{11}$ for example, explained: 'At our [Slovene-medium] school there's a teacher that teaches in Italian. [...] It's much easier than sticking to Slovene and trying to help the children who do not understand enough Slovene with additional explanations and attention. It's simply too complicated and burdensome.' A more magnanimous interviewee (Interviewee 2) explained the situation as follows: 'It's really easy to say in principle that this is a Slovene-medium school and everybody should teach in Slovene. But when you enter a class where only 2 or 3 children out of 11 are Slovenes, you have to face the reality that as a teacher you are expected to teach all of them, and they do not understand you. So, switching, at least partially, to Italian sometimes is not really a choice, but a necessity'

\footnotetext{
${ }^{10}$ Beside a limited study by Košuta and Toličič (1989), a first serious attempt at planning a longitudinal study on linguistic skills has recently started as a part of the INVALSI national evaluations in the schooling system. This study is currently carried out by the Italian national research institute INVALSI in collaboration with the Slovenian Research Institute in Trieste (see http://www.slori.org/progetti/priprava-drzavnih-preizkusov-znanja-v-slovenskem-jezikuin-prevod-drzavnih-preizkusov-znanja-v-matematiki-invalsi/).

${ }^{11}$ Interviewees in this study are numbered from 1 to 10 and will be referred to as Interviewee 1 , Interviewee 2, etc., in order to ensure their anonymity.
} 
The rising percentage of children who do not speak the minority language (or do so poorly) when they enrol in Slovene-medium kindergartens and schools (Bogatec 2010) is an important factor that clearly determines the starting point of a teacher. Regardless, the question is why educational institutions are so ineffective in bringing children up to speed in a longer period, e.g. 5 to 7 years. Are there possibly other factors beyond teaching, teaching methods and teaching skills, that play an important role and should be taken into account and dealt with when trying to improve the situation?

In order to explore possible answers to this question, it is necessary to widen our perspective beyond teaching skills, methods and models, and explore other approaches, from different disciplines, that can shed some light on why it is so difficult to improve linguistic skills of pupils enrolled in Slovene-medium and bilingual schools and kindergartens in Italy.

\section{Theoretical Approaches and Perspectives towards Minority}

\section{Language Acquisition}

A number of disciplines and approaches attempted to clarify the intricate question why some learn a minority language and others do not, and why then some use it and some do not?

Since the core issue seems to be language acquisition, the first field to be studied is education, where researchers have developed models and methods of bilingual or multilingual education and training, and second language acquisition (Skutnabb-Kangas 1981; 2000; Skutnabb-Kangass and Cummins 1988; Baker 2001; Spolsky 1990; Thomas and Collier 1997; Cummins 1979; 2000) that are commonly used and referred to when dealing with minority language acquisition. In the case of Slovenes in Italy, extensive quantitative longitudinal research is being carried out on Slovene-medium schools and kindergartens and the challenges they face (Bogatec et al. 2008; Bogatec 2010). Other studies focused on the connection between early education and teaching with minority language acquisition and language use (Pertot 2004; Mezgec 2008).

However, in order to obtain a broader view of the issue of language acquisition that also encompasses the (indirect) impact of other factors (and is not limited to the structured teaching process), the work of researchers in other disciplines, such as sociology, social psychology, sociolinguistics and linguistics, should also be considered. With different models, schemes and approaches (Fishman 1991; 2001; Gardner and Lambert 1972; Giles and Smith 1979; Baker 1992; Crystal 2000; Gumperz 1982), with concepts such as ethnolinguistic vitality (Giles et al. 1977), researchers in these disciplines examine 
the status and prestige of a language, its developmental perspectives in a given environment, trying to define factors affecting its position in a specific environment. The perspective of these researchers is frequently focused on the relationship between different languages in an environment - the minority language and the majority one. The focus is set on trying to identify factors and conditions that promote the acquisition and use of a certain language, including economic and social aspects (Baker and Jones 1998), vs. the factors that hinder its long-term preservation.

Another important line of study of language acquisition and use follows the motivations, habits and choices of speakers, aiming at understanding why and when individuals use a certain language (Gardner and Lambert 1972; Giles and Smith 1979). Concepts, approaches and theories in the field of sociology and social psychology further explain the relationship between majority and minority communities that live together (Tajfel 1978; Bourhis 1979; Bourdieu 1991) - generally by adopting an even wider perspective that exceeds language as the fundamental factor of distinction between two communities, focusing more on sociological factors. In the case of Slovenes in Italy, researchers in the field of psychology, sociology, socio-linguistics and linguistics have extensively studied issues of language acquisition, use, planning and choice (Bogatec et al. 2008; Vodopivec 2008; Brezigar 2009; Gliha Komac 2009; Kaučič-Baša 1997; 2002; Kosic 2010; Jagodic 2011). However, the results of these studies have rarely (if ever) been translated into policies that could lead to an improvement of the linguistic situation of the Slovene minority in Italy.

\section{Methodology}

In order to identify the main obstacles, perceived by educators to be the root causes and the hindering factors conducive to poor linguistic skills in the Slovene language, and to uncover the causes of the schools' limited ability to improve such skills, a preliminary exploratory study was carried out among teachers and educators between September 2018 and January 2019.

The study consisted of 10 individual qualitative interviews with educators and 3 focus groups carried out among teachers of kindergartens and primary Slovene-medium and bilingual schools in FVG, one focus group in each of the three former provinces of Trieste, Gorizia and Udine (with respectively 6, 11 and 4 participants). 5 qualitative interviews were carried out with educators working in the province of Gorizia, 3 in the province of Trieste and 2 in the Province of Udine. 6 interviewees were employed in kindergartens and 4 in primary schools. 


\section{Results of the Study and Discussion}

Interviewees and participants in the 3 focus groups presented an interesting and varied picture of the challenges they face when teaching (in) the Slovene language. Overall, their answers suggest that a focus on teaching approaches and materials will only take the community so far, and that a wider approach should be adopted if results were to improve. The most salient feedback from teachers in this study was categorised in three subsections.

\section{The Role of After-School Activities}

Although teachers acknowledge the importance of a supporting environment where linguistic skills could be used, practiced and transformed into a habitual behaviour, they do not fail to observe that frequently the idea of an organised supporting environment with lots of extracurricular activities that (linguistically) support the efforts of the teachers has become weak and frail. In fact, organisations providing extracurricular activities face similar challenges as Slovene-medium and bilingual kindergartens and schools. If some of the children do not understand the trainer or do not speak Slovene, the language of communication switches to Italian (there, as well). In the end, an extracurricular activity that should reinforce Slovene linguistic skills frequently fails to do so, depriving even those children who speak Slovene of the opportunity to use the language.

Moreover, teachers contributing to Focus group 2 pointed out that there were no such activities during the summer. ${ }^{12}$ One of them explained this issue as follows:

It's easier to work on linguistic skills of those children who are included in the network of Slovene extracurricular activities [...], although many children from Italian speaking families are not [...] when the school starts in September, I'm close to tears. I have children that in June spoke Slovene, and in September they are not able to utter a word in Slovene. I have to start all over again and it takes me two months to get them to the point where they were in June - in terms of linguistic skills and knowledge [...] On the other hand, what can we expect? These children live in a completely Italian environment, they haven't heard a word of Slovene for 3 months, of course they've forgotten what they learned the previous year. [Teacher in Focus group 2]

\footnotetext{
${ }^{12}$ There are, of course, a few summer camps available, most of them predominantly Italian or bilingual. However, children attend them for only a certain number of weeks, and mostly only until the age when they are deemed able to stay at home alone.
} 
Moreover, the network of extracurricular activities is rather well established in certain areas, whereas in others (e.g. Romjan or Beneška Slovenija) it is really weak, as pointed out by teachers in Focus group 2 and Focus group 3. These areas are characterised by either a traditionally weaker presence of the autochthonous minority or a stronger presence of Italians enrolled in Slovene-medium or bilingual schools.

Bearing in mind that this is a preliminary qualitative study with obvious limitations, the suggestion seems to be that the network of extracurricular activities, although necessary and important, does not fully play its role. The functioning of the network should probably be rethought, in close cooperation with schools, in order to build synergies between 'language acquisition in school' and 'after school language use.'

\section{(Lack of) Policies for Managing the Relationship between Language and Culture}

Teachers in the two focus groups in the provinces of Trieste and Gorizia (Focus group 1 and Focus group 2) and several interviewees $(6,7,8)$ pointed out that many educators (either them or others) are at a loss for how to deal with a growing population of pupils that do not identify themselves as Slovenes. In the aftermath of WW2, most pupils attending Slovene-medium schools identified themselves as Slovenes. The teacher, in that instance, was not only providing linguistic instruction, but he/she was also the bearer of the Slovene culture, the historical memory of the Slovene minority, the Slovene nation, and its values.

Nowadays, the number of children that do not identify themselves as Slovenes is growing ${ }^{13}$ and sometimes they represent the majority of the class. 'In this instance, is the teacher still supposed to impart the Slovene culture, its historical memory and its values in the same way?', asks Interviewee no. 6, explaining that at her school they frequently experience conflicts with parents regarding how a teacher approaches issues related to historical memory and historical celebrations. These refer to difficult historical circumstances where the two communities - Italian and Slovene - were on opposite sides. How to deal with the diversity of parents' political and ideological beliefs regarding these events? This is something that several teachers do not feel trained

\footnotetext{
${ }^{13}$ Pertot $(2007,273)$ points out an additional issue that has an important impact on the number of children entering the school who identify themselves as 'Slovenes.' She suggests that the rise of hybrid identities among members of the Slovenian minority in Italy is closely linked to the rise of different linguistic phenomena that deviate from the Slovene language (as spoken in Slovenia).
} 
(or equipped) for. The issue can be traced back to parents' motivations and reasons for minority language acquisition. As Gardner and Lambert (1972) suggested, there are affective reasons and economic reasons to learn a language. And whereas affective reasons go hand in hand with the transmission of culture, traditions, values and historical memories, the same could not be said of those who see in Slovene-language acquisition only its economic value - the value of knowing an additional language, without the burden of also having to accept its culture and historical memory.

\section{Environmental Factors}

Several interviewees and teachers in Focus groups 2 and 3 pointed at some important factors that are hindering better language acquisition in school settings. Interviewee 5 explained it as follows: 'It's difficult to teach children that the Slovene language is important and has a value, if they don't ever experience it outside the school setting. They go to the store, and everybody speaks Italian, their neighbours speak mostly Italian, they watch TV in Italian, all around them it's only Italian. Then, of course, it's normal for the child to perceive that Italian is an important language, worth learning, and Slovene is not.'

Within Focus group 2, a teacher explained the issue further:

It's very subtle. You can't point out one single big issue, but children are very perceptive [...] [they] form their opinion on the importance of the language and the community based on all those little signs they see. You still have children from Italian families that have never been across the border. Some of them don't even understand that there are people somewhere who actually use the Slovene language as a daily means of communication, in the cafeteria or in the shop [...].

Inherent in these observations is the realisation that the perception of the community in a wider context should not be underestimated. And the fact that the community is still rather closed, rarely visible as an important player in the wider Italian society, including Italian media, has an impact on language acquisition. Regardless of the attempts to improve the protection of the Slovene minority, the linguistic landscape shows little sign of the existence of the Slovene community (Mezgec 2017). These comments lead to the discussion on language prestige and the status of the language in the settlement area of the Slovene minority in Italy (Baker 1992; Baker and Jones 1998; Haugen 1966; Labov 2006). 


\section{Attitudes of Parents and Significant Others}

Beside environmental factors that have an impact on the child's perception of the language, teachers in Focus groups 1 and 2 and three interviewees pointed out that the effectiveness of early learning (and teaching) of the minority language was significantly affected by language attitudes of parents ${ }^{14}$ and significant others. Interviewee no. 7 explained it as follows:

It's incredible how much the attitudes of parents affect the child's ability to learn. One of my children has a mum who always complains that she cannot understand the notices that are published in Slovene-only on the bulletin board, and she would like them to be in [translated to] Italian, as well. The child's attitude reflects the mother's. It's always 'I don't understand.' The girl doesn't even make an effort. On the other hand, there's a dad who would take a picture of the notice with his phone and figure it out by himself. I think he throws it into google translate. And his child is doing so much better, I'm so proud of how much he has learned.

Interviewee 5 pointed out that also parents need directions:

At our first parent-teacher conference I always tell Italian parents that they have to serve as role models to the best of their abilities. If they come to school and say 'Buongiorno' instead of 'Dober dan,' the child immediately understands which language is important - and which one is not. It's not really a question of how much [Slovene language] they know, but rather if they are willing to make at least some minor effort to let know the child that what he [or she] learns here is important, that it matters to them as well.

Even more interesting is the case of a kindergarten teacher who says that not only the attitudes of parents, but also the attitudes of significant others can have an extremely important impact on children's perceptions of the value and role of the minority language, affecting, in the end, also their ability to learn it. Interviewee no. 7, for example, mentions the case of a nanny and

\footnotetext{
${ }^{14}$ Pertot (2007) points out that the significant ideological shift brought by the dissolution of Yugoslavia and the independence of Slovenia made it difficult for a part of the Slovene community in Italy to identify themselves as 'Slovenes' and gave rise to new identities. This shift towards hybrid identities, as suggested by Pertot $(2007,273)$, can have a spill over effect in the field of language, if standard language is closely linked to (standard) identity of identifying oneself as a 'Slovene.'
} 
a grandmother who had negative attitudes towards the Slovene language and the Slovene community, and how these significantly affected the two children in kindergarten, regardless of the fact that parents displayed a positive attitude both towards the community and the language.

Finally, teachers in the Focus group 1 suggested that attitudes precede action. If parents have a positive attitude towards the language, with a dedicated teacher there are also options for learning at home, even at early stages of a child's development and even if parents don't speak a word of Slovene. Interviewee no. 7 explains her own example as a kindergarten teacher as follows:

I prepare recordings of books to be used by parents. I read the book, record the reading, and at home, they can play the recorded text and watch/read the book with their child. I also ring a bell every time they need to turn the page, so that even if they don't understand anything, they can still 'read' the book in Slovene to their children. I prepare everything for them, but, of course, in the end, they have to do it.

\section{Conclusions}

Bearing in mind that this is a preliminary and rather limited study, its results suggest that a shift in focus is needed in order to achieve better results in Slovene language acquisition and use. Teachers and educators predominantly point at sociological and sociolinguistic factors as those hindering their efforts to teach the Slovene language, whereas the predominant approach that aims at improving linguistic skills currently focuses primary on linguistic and educational (didactic) issues. A number of interesting points have been raised by educators, including (but not limited to) parents' attitudes towards and use of the minority language, issues concerning language prestige, the dichotomy of economic and affective reasons for language use that clash severely in educational institutions, and the community's (in)ability to support the use of the minority language outside school walls.

The scope of the issues exposed by educators in this study seems to suggest that language acquisition (and language use) should be tackled with a broader approach that would include more awareness-raising activities among parents and significant others, more direction on how to support the child in his learning efforts by sending positive messages about the language and the community, and adjusting the family lifestyle in such a way that the child has as much contact with the language as possible outside the school setting. 
Finally, the study suggests that there is a pressing need for schools (or possibly even the community) to deal with historical divides, take a clear stand on the approach that they intend to adopt (monocultural, multicultural or intercultural), and communicate it clearly to the parents up-front, in order to avoid later disagreements or negative surprises.

\section{References}

Baker, Colin. 1992. Attitudes and Language. Clevedon: Multilingual Matters.

- 2001. Foundations of Bilingual Education and Bilingualism. Clevendon: Multilingual Matters.

Baker, Colin, and Prys Jones. 1998. Encyclopedia of Bilingual Education and Bilingualism. Clevedon: Multilingual Matters.

Bogatec, Norina, ed. 2004a. Slovene: The Slovene Language in Education in Italy. Ljouwert and Leeuwarden: Mercator Education.

- 2004b. Slovenska državna šola v Italiji pod drobnogledom: rezultati projekta o vrednotenju šolskih storitev EVAŠOL 2003. Trieste: Slori.

- 2010. 'Projekt šola 2010: predstavitev rezultatov.' http://www.slori.org/ pdf/predstavitevSOLA2010.pdf

Bogatec, Norina, and Milan Bufon, 1996. Slovenske šole v tržaški in goriški pokrajini: vrtci in osnovne šole. Trieste: Slori.

—_. 1999. Slovenske šole v tržaški in goriški pokrajini: nižje srednje in višje srednje šole. Trieste: Slori.

Bogatec, Norina, Marijan Kravos, and Veronika Lokar, eds. 2008. Projekt Mozaik: učinki večetničnega okolja na osnovno šolanje. Trieste: Sklad Libero in Zora Polojaz, Šolska mreža Projekt Mozaik, and Slovenski raziskovalni inštitut Slori.

Bourdieu, Pierre. 1991. Language and Symbolic Power. Cambridge: Polity Press.

Bourhis, Richard Y. 1979. 'Language in Ethnic Interaction: A Social Psychological Approach.' In Language in Ethnic Interactions, edited by Howard Giles and Bernard Saint-Jacques, 117-41. Oxford: Pergamon Press.

Brezigar, Sara. 2007. 'Marketing Minority Language as a Valid Tool in the Fight for Survival of Minority Languages: The Case of the Slovenes in Italy.' Treatises and Documents, Journal of Ethnic Studies, no. 52: 198-215.

- 2009. 'The Slovene Language in Italy: Paths to a Value-Added Position.' In Rights, Promotion and Integration Issues for Minority Languages in Europe, edited by Suzana Pertot, Tom Priestly, and Colin H. Williams, 207-15. Basingstoke and New York: Palgrave Macmillan.

- 2013. 'Ali se jezikovna skupnost v Furlaniji Julijski krajini lahko širi? Poučevanje in učenje slovenščine med večinskim prebivalstvom kot perspektiva za dolgoročno ohranjanje manjšinskega jezika.' In Med drugim in tujim jezikom, edited by Devan Jagodic and Štefan Čok, 97-119, 105-29. Trieste: Ciljno začasno združenje 'Jezik-Lingua!' 
2015. 'Avoiding the Dinosaur Path: An Evaluation of the Status Quo and Developmental Perspectives of the Slovene Minority in Italy.' In Dominated Languages in the 215t Century: Papers from the International Conference on Minority Languages XIV, edited by Barbara Schrammel-Leber and Christina Korb, 148-67. Grazer Plurilingualismus Studien 1. Graz: Karl-FranzensUniversität.

—. 2017. 'Slovenska skupnost v Italiji med preteklostjo in prihodnostjo.' In Skupnost v središču Evrope: Slovenci v Italiji od padca Berlinskega zidu do izzivov tretjega tisočletja, edited by Norina Bogatec, Zaira Vidau, and Gorazd Bajc, 21-33. Trieste: ZTT, Slori.

Brezigar, Sara, and Sofija Zver. 2019. 'Priprava učnih gradiv za poučevanje slovenščine v Furlaniji-Julijski krajini: študija primera in razvojne možnosti.' Treatises and Documents: Journal of Ethnic Studies, no. 83: 51-66.

Crystal, David. 2000. Language Death. Cambridge: Cambridge University Press. Cummins, Jim. 1979. 'Linguistic Interdependence and the Educational Development of Bilingual Children.' Review of Educational Research 49 (2): 22251.

. 2000. Language, Power and Pedagogy. Clevedon: Multilingual Matters Ltd.

Fatur, Silvo. 1989. 'Dileme slovenske šole v Italiji.' Primorska srečanja, no. 89-90: 11-13.

Fishman, Joshua A. 1991. Reversing Language Shift: Theoretical and Empirical Foundations of Assistance to Threatened Languages. Clevendon: Multilingual Matters.

Fishman, Joshua A., ed. 2001. Can Threatened Languages be Saved? Reversing Language Shift, Revisited: A 21st Century Perspective. Clevendon: Multilingual Matters.

Gardner, Robert C., and Wallace E. Lambert. 1972. Attitudes and Motivation in Second Language. Rowley: Newbury House.

Giles, Howard, and Philip M. Smith. 1979. 'Accomodation Theory: Optimal Level of Convergence.' In Language: Social Psychological Perspectives, edited by Howard Giles and Robert N. St. Clair, 45-65. Oxford: Blackwell.

Giles, Howard, Richard Y. Bourhis, and D. M. Taylor. 1977. 'Towards a Theory of Language and Ethnic Group Relations.' In Language, Ethnicity and Intergroup Relations, edited by Howard Giles, 307-48. London, New York, San Francisco, CA: Academic Press.

Gliha Komac, Nataša. 2009. Slovenščina med jeziki Kanalske doline. Ljubljana: Fakulteta za družbene vede; Ukve: Slovensko kulturno središča Planika Kanalska dolina; Trieste: Slori.

Grgič, Matejka. 2017. 'Teoretska izhodišča in metodološki okvir pri izdelavi uporabnikom prijaznega spletišča: primer platforme SMeJse - slovenščina kot manjšinski jezik.' In Slovenščina $v$ dvojezičnih okoliščinah, edited by 
Vojko Gorjanc, Iztok Kosem, Matejka Grgič, and Sonja Novak Lukanovič, 85-112. Ljubljana: Trojina, zavod za uporabno slovenistiko.

Haugen, Einar, 1966. 'Semicommunication: The Language Gap in Scandinavia.' Sociological Inquiry 36 (2): 280-97.

Jagodic, Devan. 2011. 'Between Language Maintenance and Language Shift: The Slovenian Community in Italy Today and Tomorrow.' Eesti ja soomeugri keeleteaduse ajakiri 2 (1): 195-213.

Jagodic, Devan, and Štefan Čok, eds. 2013. Med drugim in tujim jezikom: poučevanje in učenje slovenščine pri odraslih v obmejnem pasu Furlanije Julijske krajine. Trieste: Ciljno začasno združenje 'Jezik-Lingua.'

Kaučič-Baša, Majda. 1994. Slovenska šola na Tržaškem: sociolingvistična presoja. Trieste, Gorizia, and Udine: Slavistično društvo.

— 1997. 'Where Do Slovenes Speak Slovene and to Whom? Minority Language Choice in Transactional Settings.' International Journal of Sociology of Language 124:51-73.

- 2002. 'Scelta del codice linguistico e status della lingua: II caso degli sloveni in Italia.' In Lingue di confine, confini e fenomeni linguistici: Parallela 8, edited by Patricia Cordin, Rita Franceschini, and Gudrun Held, 197-216. Rome: Bulzoni.

Kosic, Marianna. 2010. Patterns of ingroup identification and outgroup attitudes on the Italo-Slovene borderland. Trieste: IUIES.

Košuta, Egidij, and Ivan Toličič. 1989. Raziskava o stopnji obvladovanja slovenskega in italijanskega knjižnega jezika pri otrocih vpisanih v slovenskih šolskih vrtcih na Tržaškem. Trieste: Slori.

Labov, William. 2006. The Social Stratification of English in New York. Cambridge: University of Cambridge Press.

Maver, Martin. 2015. Šola, družina in zunajšolske dejavnosti. Trieste: Združenje slovenskih športnih društev v Italiji and Slovenski raziskovalni inštitut.

Mezgec, Maja. 2008. 'Razvoj funkcionalne pismenosti v manjšinskem jeziku: primer študije med slovensko manjšino v Italiji.' In Sodobne strategije učenja in poučevanja, edited by Vida Medved Udovič, Mara Cotič, and Majda Cencič, 106-16. Koper: Pedagoška fakulteta.

_ 2016. 'Linguistic Landscape as a Mirror: The Case of the Slovene Minority in Italy.' Treatises and Documents: Journal of Ethnic Studies, no. 77: 67-85.

Pertot, Susanna. 2002. Občutek narodnostne in geografske pripadnosti maturantov šol s slovenskim učnim jezikom v Trstu: primerjava rezultatov projektivni testov, izvedenih v letih 1990 in 2000 . Gorizia: Slori.

, ed. 2004. Jezikovna vzgoja v vrtcu: vidiki vzgojiteljic. Gorizia: Slori.

- 2007. 'V imenu očeta: medgeneracijski prenos slovenskega jezika in identitete po moški liniji.' In Živeti mejo, edited by Miran Košuta, 263-75. Zbornik Slavističnega društva Slovenije 18. Trieste and Ljubljana: Slavistično društvo Slovenije. 
- 2009. 'Slovensko šolstvo v Italiji: primerjalna študija.' In Izobraževanje za dvojezičnost v kontekstu integracijskih procesov, edited by Lucija Čok, 191204. Koper: Annales.

_. 2011. 'Identitetne spremembe med Slovenci v Italiji v družinah učencev šol v slovenskim učnim jezikom v Italiji.' Treatises and Documents: Journal of Ethnic Studies, no. 66: 24-66.

Petrič, Ernest. 1977. Mednarodnopravno varstvo narodnih manjšin. Maribor: Obzorja.

Ministero dell'Interno. 1994. 'Popolazioni di lingua slovena.' In Primo rapporto sullo stato delle minoranze in Italia, 273-78. Rome: Ministero dell'interno.

Skutnabb-Kangas, Tove. 1981. Bilingualism or Not: The Education of Minorities. Clevendon: Multilingual Matters.

- Tove. 2000. Linguistic Genocide in Education - Or Worldwide Diversity and Human Rights? Mahwah, NJ: Lawrence Erlbaum Associates.

Skutnabb-Kangas, Tove, and Jim Cummins. 1988. Multilingual Education. Clevendon: Multilingual Matters.

Slosport. 2016. 'ZSŠDI: predstavili novo in hvalevredno pobudo »Jezikovni poligon.«' Slosport, 16. maj. https://www.slosport.org/novica/zssdi -predstavili-novo-in-hvalevredno-pobudo-jezikovni-poligon

Spolsky, Bernard. 1990. Conditions for Second Language Learning. Oxford: Oxford University Press.

Strani, Primož, ed. 2011. Šola na obronkih slovenščine - Metodološki in didaktični vidiki poučevanja slovenščine kot drugega ali tujega jezika v Furlaniji Julijski krajini. Trieste: Državna agencija za razvoj šolske avtonomije, Območna enota za Furlanijo Julijsko krajino.

Tajfel, Henry. 1978. 'Social Categorization, Social Identity and Social Comparison.' In Differentiation between Social Groups, edited by Henry Tajfel, 61-76. London: Academic Press.

Thomas, Wayne P., and Virginia P. Collier. 1997. 'Two Languages Are Better than One.' Educational Leadership 55 (4): 23-26.

Vodopivec, Nika. 2008. 'Language Practices, Ideologies and Planning in the Cross-Border Area of Nova Gorica (Slovenia) and Gorizia (Italy) - From Case Study to Models of Analysis and Planning in European Borderlans.' PhD dissertation, University of Trieste. 